\title{
Acylation-stimulating protein: effect of acute exercise and endurance training
}

Citation for published version (APA):

Schrauwen, P., Hesselink, M. K., Jain, M., \& Cianflone, K. (2005). Acylation-stimulating protein: effect of acute exercise and endurance training. International Journal of Obesity, 29(6), 632-638.

https://doi.org/10.1038/sj.ijo.0802949

Document status and date:

Published: 01/01/2005

DOI:

10.1038/sj.ijo.0802949

Document Version:

Publisher's PDF, also known as Version of record

Document license:

Taverne

Please check the document version of this publication:

- A submitted manuscript is the version of the article upon submission and before peer-review. There can be important differences between the submitted version and the official published version of record.

People interested in the research are advised to contact the author for the final version of the publication, or visit the DOI to the publisher's website.

- The final author version and the galley proof are versions of the publication after peer review.

- The final published version features the final layout of the paper including the volume, issue and page numbers.

Link to publication

\footnotetext{
General rights rights.

- You may freely distribute the URL identifying the publication in the public portal. please follow below link for the End User Agreement:

www.umlib.nl/taverne-license

Take down policy

If you believe that this document breaches copyright please contact us at:

repository@maastrichtuniversity.nl

providing details and we will investigate your claim.
}

Copyright and moral rights for the publications made accessible in the public portal are retained by the authors and/or other copyright owners and it is a condition of accessing publications that users recognise and abide by the legal requirements associated with these

- Users may download and print one copy of any publication from the public portal for the purpose of private study or research.

- You may not further distribute the material or use it for any profit-making activity or commercial gain

If the publication is distributed under the terms of Article $25 \mathrm{fa}$ of the Dutch Copyright Act, indicated by the "Taverne" license above, 


\title{
Acylation-stimulating protein: effect of acute exercise and endurance training
}

\author{
P Schrauwen $^{1 *}$, MKC Hesselink ${ }^{2}$, M Jain $^{3}$ and K Cianflone ${ }^{3}$ \\ ${ }^{1}$ Department of Human Biology, Nutrition and Toxicology Research Institute Maastricht (NUTRIM), Maastricht University, \\ The Netherlands; ${ }^{2}$ Department of Movement Sciences, Nutrition and Toxicology Research Institute Maastricht (NUTRIM), \\ Maastricht University, The Netherlands; and ${ }^{3}$ McGill Unit for the Prevention of Cardiovascular Disease, McGill University \\ Health Centre, Montreal, Canada
}

INTRODUCTION: Acylation-stimulating protein (ASP) is an adipocyte-derived protein that contributes to fatty acid clearance. Regular exercise training improves fatty acid handling.

OBJECTIVE: To examine the effect of acute exercise and short-term endurance training on ASP levels.

SUBJECTS: Eight untrained men (age: $23.5 \pm 3.4 \mathrm{y}$; maximal power output $\left(W_{\max }\right): 3.7 \pm 0.6 \mathrm{~W} / \mathrm{kg}$ body weight).

DESIGN: Subjects were trained for 2 weeks. Before and after training, blood was sampled during a 3-h exercise test, and insulin sensitivity was assessed by an insulin tolerance test.

RESULTS: Before training, ASP levels decreased during exercise (from $17.9 \pm 2.9$ to $15.5 \pm 3.7 \mathrm{nmol} / \mathrm{l}$ at $t=0$ vs $180, P<0.05$ ). Endurance training decreased fasting ASP levels significantly $(17.9 \pm 2.9$ vs $13.4 \pm 2.3 \mathrm{nmol} / \mathrm{l}$ pre- and post-training, $P<0.001)$. Interestingly, after 2 weeks of endurance training, ASP levels tended to increase during exercise (from $13.4 \pm 2.3$ to $17.2 \pm 4.5 \mathrm{nmol} / \mathrm{l}$ at $t=0$ vs $180, P=0.09$ ). Baseline ASP levels correlated negatively with insulin sensitivity both before $(r=-0.86, P<0.01)$ and after training $(r=-0.82, P<0.05)$.

CONCLUSION: Short-term endurance training reduces baseline ASP levels. These data fit with the hypothesis that reduced ASP levels indicate improved ASP sensitivity.

International Journal of Obesity (2005) 29, 632-638. doi:10.1038/sj.ijo.0802949

Published online 5 April 2005

Keywords: acylation stimulating protein; fatty acids; insulin sensitivity; endurance training

\section{Introduction}

Acylation-stimulating protein (ASP) is an adipocyte-derived protein that promotes glucose uptake and TG synthesis in adipose tissue. ${ }^{1,2}$ ASP can do so by stimulating the translocation of glucose transporters to the cell membrane of the adipocyte, ${ }^{3,4}$ and by stimulation of fatty acid esterification ${ }^{1}$ likely via activation of the enzyme diacylglycerol acyltransferase (DGAT), which catalyses the final step in triglyceride synthesis. ${ }^{1}$ Further, Van Harmelen et al. ${ }^{5}$ demonstrated that ASP also decreases intracellular lipolysis and release of fatty acid from adipocytes. ASP, identical to C3adesArg, is derived through the cleavage of complement $\mathrm{C} 3$ via the interaction of $\mathrm{C} 3$, factor $\mathrm{B}$ and adipsin. ${ }^{6}$ Therefore, mice lacking C3 have

${ }^{*}$ Correspondence: Dr P Schrauwen, Department of Human Biology, Nutrition and Toxicology Research Institute Maastricht (NUTRIM), Maastricht University, PO Box 616, NL-6200 MD Maastricht, The Netherlands.

E-mail: p.schrauwen@hb.unimaas.nl

Received 21 April 2004; revised 21 February 2005; accepted 23 February 2005; published online 5 April 2005 been used to examine the effect of ASP deficiency on fatty acid metabolism. Indeed, it has been shown that ASPdeficient C3 (-/ -$)$ mice have a reduced body fat mass and a delayed triglyceride clearance. ${ }^{7-9}$

In humans, it has been shown that the subcutaneous adipose tissue produces ASP locally in the postprandial state, and this release correlates with the extent of fatty acid trapping in the adipose tissue. ${ }^{10}$ Altogether, these data suggest that ASP might be an important factor in regulating fatty acid metabolism in white adipose tissue and thereby also controlling plasma fatty acid levels. In this context, obese and type 2 diabetic humans have increased levels of plasma ASP, ${ }^{11,12}$ and these subjects are characterized by disordered fatty acid metabolism and insulin resistance. ${ }^{13}$ Therefore, Cianflone et al. ${ }^{14}$ recently suggested that increased plasma ASP levels might be a marker of cellular ASP resistance. ${ }^{12}$

If ASP resistance is indeed an existing phenomenon, then endurance training might be hypothesized to improve ASP resistance/sensitivity. During acute exercise, lipolytic rate in white adipose tissue is rapidly increased to release fatty acids 
in the blood as a substrate for muscular oxidation. The release of free fatty acids (FFA) from the adipose tissue, however, exceeds uptake by peripheral tissue and the net result is an increase in plasma FFA levels up to very high levels. However, regular exercise training improves many aspects of fatty acid metabolism. ${ }^{15-18}$ For example, the increase in plasma FFA levels during acute exercise of a similar intensity is lower in trained subjects, probably due to a blunted sympatho-adrenic-induced lipolysis ${ }^{19-22}$ and an improved fatty acid re-esterification, ${ }^{23,16}$ both indicating an improved fatty acid handling. It could therefore be hypothesized that endurance training might lead to a reduction in basal ASP levels, indicating improved ASP sensitivity. For this goal, we examined the effect of a 2-week, controlled exercise training program ${ }^{24}$ on plasma FFA and ASP levels during exercise.

\section{Methods}

\section{Subjects}

Eight young, untrained, healthy male subjects (age: 23 . $5 \pm 3.4$ y; BMI: $22.4 \pm 2.7 \mathrm{~kg} / \mathrm{m}^{2} ; W_{\max }: 3.7 \pm 0.6 \mathrm{~W} / \mathrm{kg}$ body weight (BW)) participated in this study. Subjects were recruited by advertisement and were excluded from participation if they had performed aerobic exercise competitively for more than 3 months or were still exercising on a regular basis. The study was approved by the institutional Medical Ethics Committee. Subjects gave their written informed consent after the nature of the procedure was explained. Some of these subjects formed the basis of a previous study on the effect of short-term training on intramyocellular lipid content. $^{24}$

\section{Experimental protocol}

A week preceding the experimental trial, an incremental test to determine maximal power output $\left(W_{\max }\right)$ and maximal oxygen consumption $\left(\mathrm{VO}_{2 \max }\right)$ was performed, which was repeated in the week after the experimental trial.

Subjects started with a standardization period for 3 days (days 1-3), during which a standardized diet was provided and subjects refrained from exercise. In the afternoon of day 3 , after a $4 \mathrm{~h}$ fast, the subjects performed a submaximal cycling test at $40 \%$ of their predetermined $W_{\text {max }}$. Substrate oxidation during the test was measured by indirect calorimetry and blood samples were taken every hr. Subjects then participated in a 12-day training program with either $2 \mathrm{~h}$ of endurance exercise or $45 \mathrm{~min}$ of intermittent exercise training, alternating on a daily base. Resting days were incorporated on days 4 and 10. After the training session, subjects again followed a standardization period for 3 days (days 15-17), with the same standardization diet as on days 1-3 and during which subjects refrained from exercise. In the afternoon of day 17, the subjects again performed a submaximal exercise test at $40 \% W_{\max }$, with substrate oxidation being measured and blood being sampled. Insulin sensitivity was assessed by an insulin tolerance test (ITT) in the mornings of days 2 and 16, after an overnight fast. To ensure that training-induced alterations in insulin sensitivity were examined rather than the remnant effect of the final training session, the ITT was planned in the morning of day 16 , so that there was a $48 \mathrm{~h}$ period in between the last training session and the ITT.

\section{Diets}

The standardization diet consisted of 30\% energy as fat, 55\% energy as carbohydrate and 15\% energy as protein. Subjects were given a fixed amount of food $(1.65 \times$ BMR based on Harris and Benedict equations ${ }^{25}$ ) and were asked to eat all the food provided, and nothing else. The diet consisted of breakfast, lunch, ready to use dinner and snacks.

\section{Procedures}

Maximal performance. Maximum workload $\left(W_{\max }\right)$ and maximum oxygen uptake $\left(\mathrm{VO}_{2 \max }\right)$ were determined on an electronically braked cycle ergometer (Lode Excalibur, Groningen, The Netherlands) during an incremental exhaustive exercise test ${ }^{26} 1$ week before the experimental trial. Oxygen uptake was measured by indirect calorimetry (Oxycon- $\beta$, Mijnhardt, Mannheim, Germany). The test was repeated 1 week after the experimental trial.

3-h cycling test. The exercise test consisted of $3 \mathrm{~h}$ of cycling on an ergometer at an intensity of $40 \%$ of the predetermined $W_{\text {max }}$. During the exercise test, substrate oxidation was measured every $15 \mathrm{~min}$ using indirect calorimetry (Oxycon- $\beta$, Mijnhardt, Mannheim, Germany) and blood samples were collected every $60 \mathrm{~min}$. To facilitate the completion of the exercise test, subjects received $125 \mathrm{ml}$ of a maltodextrine drink (Extran Fresh Citrus; 131 kJ/31 kcal, 7.9 g carbohydrate, $0 \mathrm{~g}$ protein and lipid per $100 \mathrm{ml}$ ) twice during the second half of the test (at $t=90$ and $135 \mathrm{~min}$.). Subjects were allowed to drink water ad libitum during the whole test. Fat and carbohydrate oxidation were calculated based on respiratory quotient (RQ) values according to Peronnet. ${ }^{27}$

Training program. From day 5 to 14 , subjects reported to the laboratory daily to follow supervised training sessions on cycle ergometers (Lode Excalibur, Groningen, The Netherlands), except for the resting day on day 10. Training consisted of alternating days of interval and endurance training, and always started with $7.5 \mathrm{~min}$ of warming up at $40 \% W_{\max }$ and ended with $7.5 \mathrm{~min}$ of cooling down at $40 \% W_{\text {max }}$. On days 5 , 7, 9 and 11, intermittent exercise training was performed, which consisted of $45 \mathrm{~min}$ of alternating 3-min intervals at $70 \% W_{\max }$ and $35 \% W_{\max }$. At days 6, 8, 12 and 14, exercise consisted of $35 \mathrm{~min}$ at $55 \% W_{\max }$, followed by $35 \mathrm{~min}$ at $50 \% W_{\max }$, and $35 \mathrm{~min}$ at $45 \% W_{\max }$, for a total duration of $120 \mathrm{~min}$. 
Insulin tolerance test (ITT). ITTs were performed as previously described ${ }^{28}$ in the fasted state in the morning of days 2 and 16. Briefly, the fall in plasma glucose in response to the injection of human insulin $(0.1 \mathrm{U} / \mathrm{kg}$ BW, Actrapid, Novo Nordisk A/S, Denmark) was monitored every 2 min during $16 \mathrm{~min}$. Insulin was injected via a catheter in the anticubital vein, while arterialized blood samples were obtained via a catheter inserted into a dorsal vein of the contralateral hand, which was warmed in a heated air box at $60^{\circ} \mathrm{C}$. Since no changes were noted within 4 min after administration of insulin, the first $4 \mathrm{~min}$ were not considered in the analysis. Linear regression was used to fit a line through the plasma glucose values between 4 and $16 \mathrm{~min}$. The time until half of the glucose had disappeared $\left(t_{1 / 2}\right)$ was calculated and taken as an indicator of insulin resistance. Therefore, insulin sensitive subjects will have a low, while insulin resistant subjects will have a high $t_{1 / 2}$.

\section{Blood analyses}

ASP was measured by a monoclonal-polyclonal sandwich ELISA assay as described in detail previously. ${ }^{10,29}$ In one subject, fasting ASP could not be determined post-training due to technical problems. For determination of FFA, glycerol, triglycerides and glucose, blood was collected in tubes containing $30 \mu \mathrm{l}$ of $0.2 \mathrm{M}$ EDTA. Plasma was immediately centrifuged at high speed, frozen in liquid nitrogen and stored at $-80^{\circ} \mathrm{C}$ for later analyses. FFA were determined using the Wako NEFA C test kit (Wako chemicals, Neuss, Germany). Plasma glucose was determined using the hexokinase method (LaRoche, Basel, Switzerland) and triglycerides and glycerol using the GPO-trinder (sigma).

\section{Statistics}

Data is presented as mean \pm standard error of the mean (s.e. $\mathrm{m}$.). Differences before and after training in selected parameters were detected with paired Student's $t$-tests. The level of ASP during exercise was analyzed with two-way repeated-measures ANOVA. If the repeated-measures analyses detected significant differences, a Bonferonni post hoc test was performed to localize the differences. Pearson correlation coefficients were calculated to determine the relationship between selected variables. $P$-values $<0.05$ were considered statistically significant.

\section{Results}

\section{Maximal performance}

Maximal performance tended to be increased after the training program $(272.3 \pm 15.8$ vs $282.5 \pm 15.2 \mathrm{~W}$ pre- and post-training, $P=0.07$ ). Maximal oxygen consumption was not significantly altered by training $(3.5 \pm 0.2$ vs $3.6 \pm 0.21 /$ min pre- and post-training, NS).

\section{Plasma ASP levels}

The 2-week endurance training program resulted in a significant $25 \%$ decrease in fasting ASP levels $(17.9 \pm 2.9$ vs $13.4 \pm 2.3 \mathrm{nmol} / \mathrm{l}$ pre- and post-training, Figure $1, P<0.001)$. During exercise, a significant time $v s$ training effect for ASP was detected $(P<0.05)$. Before the training period, ASP levels decreased significantly during the $3 \mathrm{~h}$ exercise bout (from $17.9 \pm 2.9$ to $15.5 \pm 3.7 \mathrm{nmol} / \mathrm{l}$ at $t=0$ vs 180 , Figure 1, $P<0.05)$. After 2 weeks of endurance training, ASP levels tended to increase slightly but not significantly during exercise (from $13.4 \pm 2.3$ to $17.2 \pm 4.5 \mathrm{nmol} / 1$ at $t=0$ vs 180 , Figure $1, P=0.09$ ).

The time until half of the glucose had disappeared $\left(t_{1 / 2}\right)$, as an indicator of insulin sensitivity, was more rapid after 2 weeks of endurance training, but the differences did not reach statistical significance $(15.4 \pm 1.4$ vs $14.1 \pm 1.1 \mathrm{~min}$, $P=0.12$ ). Interestingly, baseline ASP levels correlated positively with glucose half-time (i.e. insulin resistance) both before $(r=0.86$, Figure $2, P<0.01)$ and after training $(r=0.82$, Figure $2, n=7, P<0.05)$.

\section{Blood parameters}

There were no significant differences before and after training in the fasting plasma values of glucose, FFA, glycerol and triglycerides.

Plasma FFA levels increased significantly during the $3 \mathrm{~h}$ exercise bout, both before (from $180 \pm 26$ to $999 \pm 58 \mu \mathrm{mol} / 1$ at $t=0$ vs $t=180$, Figure $3, P<0.05)$ and after the training period (from $212 \pm 32$ to $798 \pm 68 \mu \mathrm{mol} / \mathrm{l}$ at $t=0$ vs 180, Figure $3, P<0.05)$. However, the area under FFA concentration vs time curve was significantly lower after the 2-week training program $(517 \pm 49$ vs $393 \pm 17 \mu \mathrm{molh} / \mathrm{l}$ pre- and post-training, $P<0.05)$. Plasma glycerol levels increased significantly during the $3 \mathrm{~h}$ exercise bout, both before (from

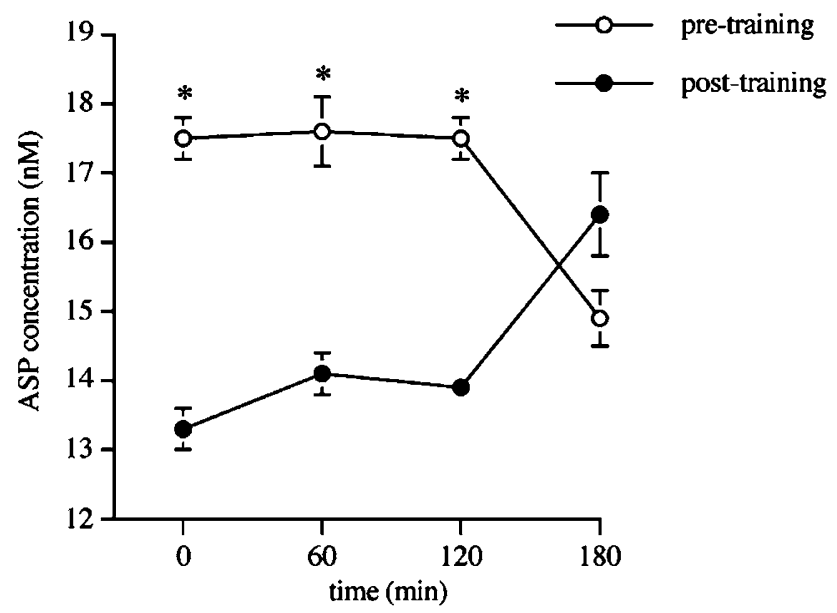

Figure 1 ASP plasma concentrations during the 3-h cycling test. $O$, pretraining, $\bullet$, post-training. Stars indicate significant differences between pre$v s$ post-training, by paired $t$-test, where ${ }^{*} P<0.05$. 

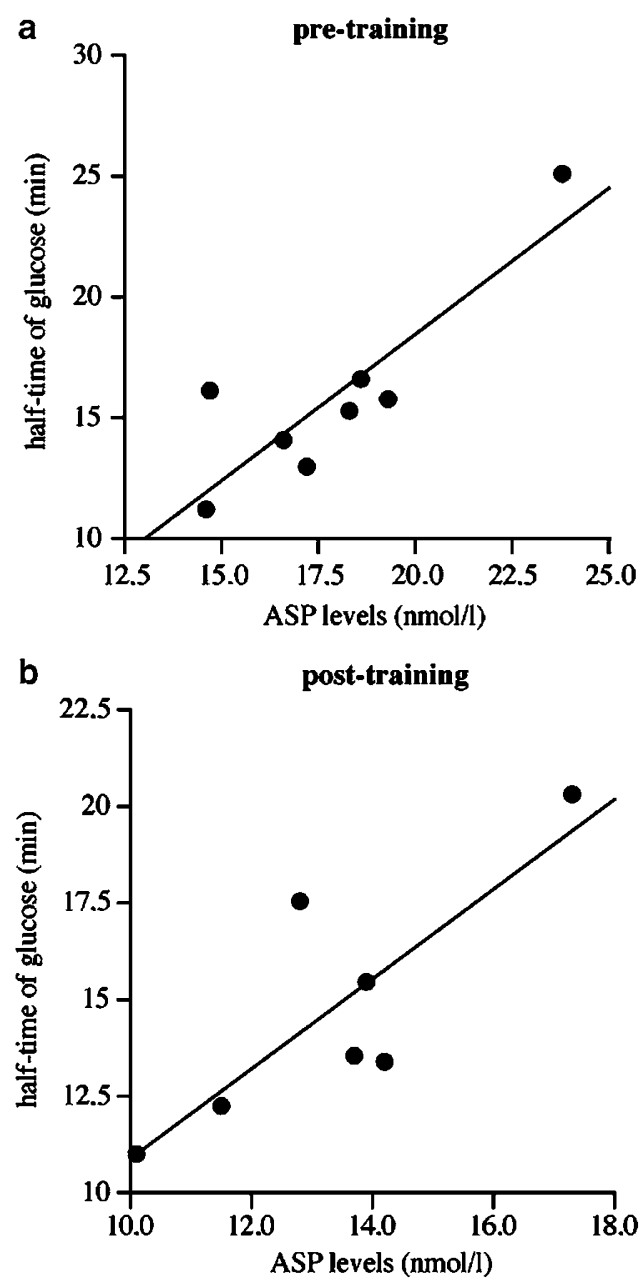

Figure 2 Relationship between fasting ASP levels and glucose $t_{1 / 2}$, (a) before $(r=0.86, P<0.01)$ and (b) after $(r=0.82, P<0.05)$ the 2- week training program.

$60 \pm 8$ to $398 \pm 46 \mu \mathrm{mol} / \mathrm{l}$ at $t=0$ vs 180 , Figure $3, P<0.05)$ and after the training period (from $63 \pm 6$ to $301 \pm 28 \mu \mathrm{mol} / \mathrm{l}$ at $t=0 v s$ 180, Figure $3, P<0.05$ ). Again, area under glycerol concentration $v s$ time curve was significantly lower after the 2 -week training program $(186 \pm 25$ vs $136 \pm 6 \mu \mathrm{molh} / 1$ pre- and post-training, $P<0.05)$. Plasma triglyceride levels decreased significantly during the $3 \mathrm{~h}$ exercise bout, both before (from $1.79 \pm 0.33$ to $0.83 \pm 0.16 \mathrm{mmol} / \mathrm{l}$ at $t=0 \mathrm{vs} 180$, Figure $3, P<0.05$ ) and after the training period (from $1.84 \pm 0.22$ to $0.88 \pm 0.16 \mathrm{mmol} / \mathrm{l}$ at $t=0$ vs 180 , Figure 3 , $P<0.05$ ), but the area under curve was not significantly different. Similarly, plasma glucose levels decreased significantly during the $3 \mathrm{~h}$ exercise bout, both before (from $5.1 \pm 0.3$ to $4.3 \pm 0.1 \mathrm{mmol} / \mathrm{l}$ at $t=0$ vs $180, P<0.05)$ and after the training period (from $5.6 \pm 0.3$ to $4.5 \pm 0.1 \mathrm{mmol} / \mathrm{l}$ at $t=0$ vs 180, $P<0.05)$, but the area under curve was not significantly different.

There were no correlations between plasma ASP levels and/ or training-induced changes in plasma ASP and plasma levels
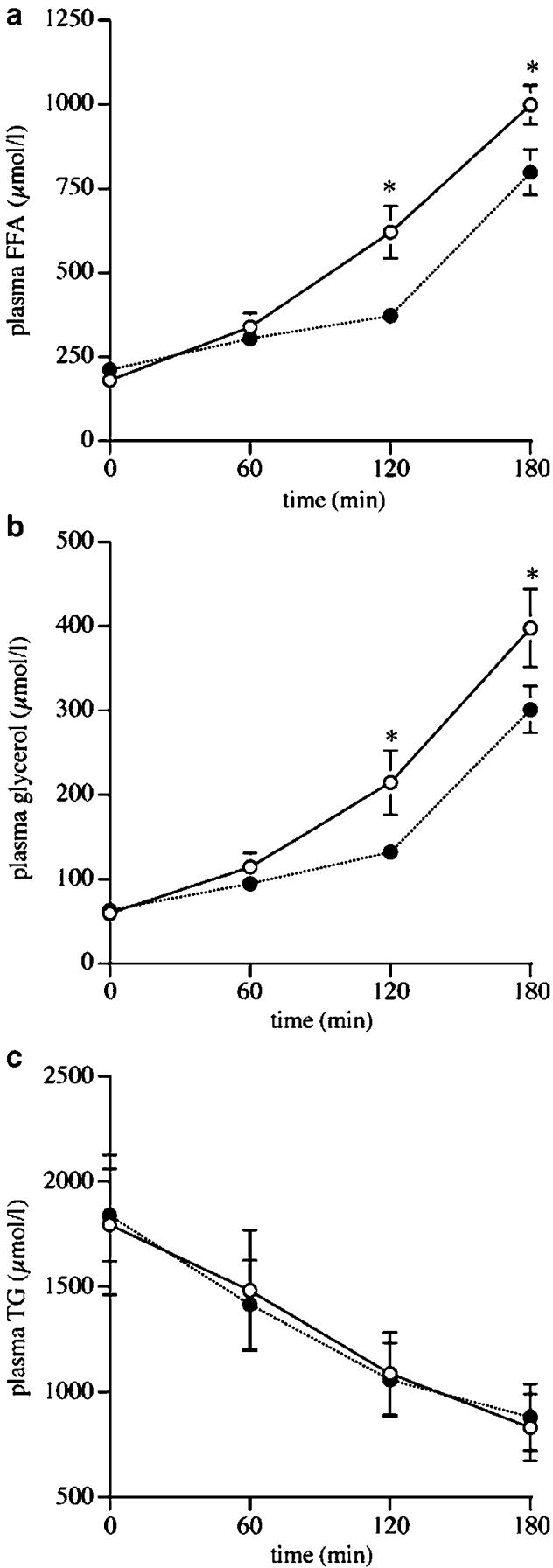

Figure 3 Plasma concentrations of (a) FFA, (b) glycerol and (c) triglycerides during the 3-h cycling test. $\bigcirc$, pre-training, $\bullet$, post-training. Stars indicate significant differences between pre- and post-training values.

of FFA, glycerol, glucose or triglycerides. Also, no correlations were found between ASP and the area under the time $v s$ concentration curves for plasma levels of FFA, glycerol, glucose or triglycerides. 


\section{Substrate oxidation}

Energy expenditure during exercise was not significantly affected by the training program $(36.0 \pm 1.7 v s 35.3 \pm 1.4 \mathrm{~kJ} /$ min pre- and post-training, NS). Similarly, RQ during exercise was not significantly affected by the training program $(0.90 \pm 0.01$ vs $0.91 \pm 0.01$ pre- and post-training, NS). Before training, baseline ASP levels correlated positively with RQ during exercise $(r=0.70, P=0.05)$, but this relationship disappeared after training.

\section{Discussion}

ASP has been suggested to be involved in the handling of fatty acids. Here we show that endurance training, a condition characterized by improved fatty acid metabolism, results in a reduction in plasma ASP levels. In addition, ASP levels were very strongly correlated with the insulin sensitivity. These data suggest that high ASP levels, as seen in obesity and diabetes, are indicative of ASP resistance and that endurance training improves ASP sensitivity.

ASP and its precursor proteins are some of many factors that are released by the adipose tissue. After being released, ASP stimulates the uptake of glucose into adipose tissue ${ }^{3,4}$ and activates the enzyme DGAT, which catalyses the final step in triglyceride synthesis. ${ }^{1}$ In this way, ASP is able to increase triglyceride storage in adipose tissue and helps to control circulating lipid levels. Interestingly, however, several studies have shown that ASP levels are high in obese subjects, possibly as a direct consequence of increased fat mass. ${ }^{30,29,11,12}$ It was recently hypothesized that these high ASP levels represent an ASP-resistant state, whereas low ASP levels indicate increased sensitivity of adipose tissue towards ASP. ${ }^{14}$ This hypothesis is supported by in vitro data. Thus, cells from subjects with high ASP levels were shown to have a reduced specific binding and response to ASP. ${ }^{31,32}$ In addition, ASP levels are increased in obese diabetic subjects, and it has been suggested by Koistinen et al. ${ }^{12}$ that the metabolic disturbances in diabetes may overcome the regulatory role of ASP on lipid and glucose metabolism, again suggesting that high ASP levels indicate ASP resistance. ${ }^{12}$ In a study of postprandial lipemia with a range of responses, higher fasting ASP predicted delayed TG clearance in both men and women. ${ }^{14}$ Furthermore, the rate of postprandial FFA clearance was inversely related to ASP levels in both men and women. ${ }^{14}$

The results of the present study are also in accordance with the concept that reduced levels of ASP indicate improved ASP sensitivity. Endurance training is well known for its stimulatory effects on fatty acid metabolism. Thus, trained subjects have a higher fat oxidative capacity, lower RQ during submaximal exercise and improved fatty acid handling. ${ }^{15-18}$ In a recent study, we showed that a 3-month low-intensity endurance training program in previously untrained, sedentary males improved fat oxidative capacity and lowered plasma triglyceride levels. ${ }^{18}$ In the present study, we could not detect any changes in fat oxidative capacity at the whole body level, probably due to the shortterm nature of the present training program. However, we did find that the increase in plasma FFA levels during exercise was already diminished after 2 weeks of endurance training, indicating improved fatty acid handling. Thus, during exercise, adipose tissue lipolysis is stimulated to supply the skeletal muscle with fatty acids as an energy substrate, but skeletal muscle cannot oxidize all fatty acids supplied and plasma FFA levels will increase. Therefore, a continuous re-esterification of fatty acids, both in adipose tissue $^{23,16}$ as in other tissues (among which skeletal muscle $)^{33}$ takes place. It has been estimated that during exercise approximately $25-40 \%$ of all fatty acids released by lipolysis are re-esterified, a number which rapidly increases to $90 \%$ at the cessation of exercise. ${ }^{23}$ Endurance training improves the rate of fatty acid re-esterification, and can thereby contribute to a better control of fatty acid levels during exercise. ${ }^{16}$ In addition, endurance training also leads to a better control of lipolysis, indicated by the lower levels of glycerol. This effect might be due to training-induced improvement of insulin sensitivity of the white adipose tissue, leading to greater inhibition of HSL activity (see below). This effect will also contribute to the improved fatty acid handling induced by endurance training.

Although it cannot be proven in the present study, the present results are consistent with the concept that reduced levels of ASP indicate improved ASP sensitivity. ASP may be important in fatty acid re-esterification in adipose tissue during and after exercise, by stimulating glucose uptake and DGAT activity. In this context, the training-induced reduction in ASP could indeed indicate improved sensitivity of the adipose tissue towards ASP, and the exercise-induced increase in ASP post training coincides with an attenuated increase in FFA and glycerol, suggesting either increased tissue esterification (via ASP) or decreased stimulation of lipolysis (via insulin-induced inhibition of HSL). This may be part of the training-induced metabolic adaptations that lead to an improved fatty acid re-esterification handling of fatty acids.

Endurance training is well known to improve insulin sensitivity. It has previously been shown that endurance training can already improve insulin sensitivity after a period of training as short as 7 days, ${ }^{34-36}$ although in some of these studies insulin sensitivity was measured shortly after the last exercise bout. In the present study, we allowed sufficient recovery time between the last bout of exercise and the determination of insulin sensitivity, but did not find statistically significant improvement of insulin sensitivity after endurance training $(P=0.12)$. This again might be due to the short-term nature of the training program, although it also cannot be excluded that the methodology used was not sensitive enough to detect small changes. In the present study, we chose to use a venous ITT, which measures the hypoglycaemic action of injected insulin, because it was recently shown to allow detection of improved insulin 
sensitivity after 6 weeks of endurance training. ${ }^{28}$ Although an improvement in insulin sensitivity was not statistically significant, a striking finding of the present study is that baseline ASP levels were very strongly related to insulin sensitivity, both before and after the training program. The direction of all these correlations was such that low levels of ASP were associated with high insulin sensitivity. The reason for this association between ASP and insulin sensitivity cannot be deduced from the present study but only inferred from studies on ASP function. ASP is known to stimulate glucose uptake into adipose tissue, ${ }^{4}$ and it could be suggested that improved ASP sensitivity, indicated by the lower ASP levels, leads to improved glucose uptake by the adipose tissue. Also, ASP has recently been shown to stimulate insulin secretion ${ }^{37}$ and an improved ASP sensitivity might thus contribute to reduced insulin levels after training, although the latter cannot be deduced from the present study. Along this line, the reduced levels of ASP after training could theoretically contribute to an improvement of insulin sensitivity after endurance training, but, for the reasons mentioned above, in the present study insulin sensitivity was not yet statistically significant improved, and therefore this hypothesis cannot be tested within the present study. Therefore, longer-term training studies are needed to examine whether increased ASP sensitivity can contribute to an improvement of insulin sensitivity.

Apart from a training-induced reduction in plasma ASP levels, we also examined the effect of submaximal exercise for $3 \mathrm{~h}$ on plasma ASP levels. As mentioned above, fatty acid re-esterification increases at the cessation of exercise and therefore an increase in ASP levels during exercise might be expected. Prior to the training program, ASP levels decreased in the final hour of the 3 -h exercise bout, with a concomitant increase in FFA. After 2 weeks of endurance training, however, plasma ASP levels tended to increase not decrease, in the final hour of the 3 -h exercise bout. The increase in ASP during exercise might be a physiological response to limit excessive increase in plasma FFA during exercise by limiting lipolysis and stimulating FFA clearance and esterification into adipose tissue, again consistent with the attenuation of the FFA increase in the trained subjects. Therefore, the ability to acutely increase ASP during exercise after training, probably together with an improved ASP sensitivity of the adipose tissue (allowing fasting plasma ASP levels to decrease) might contribute to the improved fatty acid re-esterification observed in the trained state. ${ }^{16}$ However, why ASP is decreased during exercise in untrained subjects cannot be deduced from the present study, although it could be suggested that in the untrained state the only way to enhance fat oxidation during prolonged exercise for several hours is by further increasing plasma FFA levels and this is enhanced by reduced FFA re-esterification. It should be noted that, in the trained state, the skeletal muscle relies less on the oxidation of plasma FFA but also uses intramuscular triglycerides and VLDL triglycerides as a source of energy. $^{38,18}$
In conclusion, our data show that short-term endurance training reduces baseline ASP levels. This reduction is accompanied by a diminished exercise-induced increase in NEFA. Since endurance training is known to improve fatty acid handling, these data are in accordance with the hypothesis that a reduced ASP level indicates improved ASP sensitivity.

\section{Acknowledgements}

We thank Steven Constants and Niels Boon for their help in performing this study. The research of P Schrauwen has been made possible by a fellowship of the Royal Netherlands Academy of Arts and Sciences. This project was made possible by support from CIHR (MOP-13716) to KC. KC is supported by a fellowship from FRSQ.

\section{References}

1 Yasruel Z, Cianflone K, Sniderman AD, Rosenbloom M, Walsh M, Rodriguez MA. Effect of acylation stimulating protein on the triacylglycerol synthetic pathway of human adipose tissue. Lipids 1991; 26: 495-499.

2 Cianflone K, Maslowska M, Sniderman AD. Acylation stimulating protein (ASP), an adipocyte autocrine: new directions. Semin Cell Dev Biol 1999; 10: 31-41.

3 Germinario R, Sniderman AD, Manuel S, Lefebvre SP, Baldo A, Cianflone $\mathrm{K}$. Coordinate regulation of triacylglycerol synthesis and glucose transport by acylation-stimulating protein. Metabolism 1993; 42: 574-580.

4 Tao Y, Cianflone K, Sniderman AD, Colby-Germinario SP, Germinario RJ. Acylation-stimulating protein (ASP) regulates glucose transport in the rat L6 muscle cell line. Biochim Biophys Acta 1997; 1344: 221-229.

5 Van Harmelen V, Reynisdottir S, Cianflone K, Degerman E, Hoffstedt J, Nilsell K, Sniderman A, Arner P. Mechanisms involved in the regulation of free fatty acid release from isolated human fat cells by acylation-stimulating protein and insulin. J Biol Chem 1999; 274: 18243-18251.

6 Cianflone K, Maslowska M. Differentiation-induced production of ASP in human adipocytes. Eur J Clin Invest 1995; 25: 817-825.

7 Murray I, Sniderman AD, Cianflone K. Mice lacking acylation stimulating protein (ASP) have delayed postprandial triglyceride clearance. J Lipid Res 1999; 40: 1671-1676.

8 Murray I, Sniderman AD, Havel PJ, Cianflone K. Acylation stimulating protein (ASP) deficiency alters postprandial and adipose tissue metabolism in male mice. J Biol Chem 1999; 274: 36219-36225.

9 Xia Z, Sniderman AD, Cianflone K. Acylation-stimulating protein (ASP) deficiency induces obesity resistance and increased energy expenditure in ob/ob mice. J Biol Chem 2002; 277: 45874-45879.

10 Saleh J, Summers LK, Cianflone K, Fielding BA, Sniderman AD, Frayn KN. Coordinated release of acylation-stimulating protein (ASP) and triacylglycerol clearance by human adipose tissue in vivo in the postprandial period. J Lipid Res 1998; 39: 884-891.

11 Weyer C, Pratley RE. Fasting and postprandial plasma concentrations of acylation-stimulation protein (ASP) in lean and obese Pima Indians compared to Caucasians. Obes Res 1999; 7: 444-452.

12 Koistinen HA, Vidal H, Karonen SL, Dusserre E, Vallier P, Koivisto VA, Ebeling P. Plasma acylation stimulating protein concentration and subcutaneous adipose tissue C3 mRNA expression in nondiabetic and type 2 diabetic men. Arterioscler Thromb Vasc Biol 2001; 21: 1034-1039. 
13 McGarry JD. Banting lecture 2001: dysregulation of fatty acid metabolism in the etiology of type 2 diabetes. Diabetes 2002; 51: 7-18.

14 Cianflone K, Zakarian R, Couillard C, Delplanque B, Despres JP, Sniderman AD. Fasting acylation stimulating protein is predictive of postprandial triglyceride clearance. I Lipid Res 2004; 1: 124-131.

15 Martin III WH, Dalsky GP, Hurley BF, Matthews DE, Bier DM, Hagberg JM, Rogers MA, King DS, Holloszy JO. Effect of endurance training on plasma free fatty acid turnover and oxidation during exercise. Am J Physiol Endocrinol Metab 1993; 265: E708-E714.

16 Romijn JA, Klein S, Coyle EF, Sidossis LS, Wolfe RR. Strenuous endurance training increases lipolysis and triglyceride-fatty acid cycling at rest. J Appl Physiol 1993; 75: 108-113.

17 Horowitz JF, Klein S. Lipid metabolism during endurance exercise. Am J Clin Nutr 2000; 72: 558S-563S.

18 Schrauwen P, Van Aggel-Leijssen DP, Hul G, Wagenmakers AJ, Vidal $\mathrm{H}$, Saris $\mathrm{WH}$, Van Baak MA. The effect of a 3-month low-intensity endurance training program on fat oxidation and acetyl-CoA carboxylase-2 expression. Diabetes 2002; 51: 2220-2226.

19 Winder WW, Hickson RC, Hagberg JM, Ehsani AA, McLane JA. Training-induced changes in hormonal and metabolic responses to submaximal exercise. I Appl Physiol 1979; 46: 766-771.

20 Loy SF, Conlee RK, Winder WW, Nelson AG, Arnall DA, Fisher AG. Effects of 24-hour fast on cycling endurance time at two different intensities. J Appl Physiol 1986; 61: 654-659.

21 Knapik JJ, Meredith CN, Jones BH, Suek L, Young VR, Evans WJ. Influence of fasting on carbohydrate and fat metabolism during rest and exercise in men. J Appl Physiol 1988; 64: 1923-1929.

22 Coggan AR, Kohrt WM, Spina RJ, Bier DM, Holloszy JO. Endurance training decreases plasma glucose turnover and oxidation during moderate-intensity exercise in men. I Appl Physiol 1990; 68: 990-996.

23 Wolfe RR, Klein S, Carraro F, Weber JM. Role of triglyceride-fatty acid cycle in controlling fat metabolism in humans during and after exercise. Am J Physiol 1990; 258: E382-E389.

24 Schrauwen-Hinderling VB, Schrauwen P, Hesselink MK, Van Engelshoven JM, Nicolay K, Saris WH, Kessels AG, Kooi ME. The increase in intramyocellular lipid content is a very early response to training. J Clin Endocrinol Metab 2003; 88: 1610-1616.

25 Harris JA, Benedict FG, A biometric study of basal metabolism in man. (1919). A biometric study of basal metabolism in man. Washington, Carnegie Institution of Washington.
26 Kuipers H, Saris WHM, Brouns F, Keizer HA, ten Bosch C. Glycogen synthesis during exercise and rest with carbohydrate feeding in males and females. Int J Sports Med 1989; 10: S63-S67.

27 Péronnet F, Masssicotte D. Table of nonprotein respiratory quotient: an update. Can J Sport Sci 1991; 16: 23-29.

28 Borghouts LB, Backx K, Mensink MF, Keizer HA. Effect of training intensity on insulin sensitivity as evaluated by insulin tolerance test. Eur J Appl Physiol Occup Physiol 1999; 80: 461-466.

29 Maslowska M, Vu H, Phelis S, Sniderman AD, Rhode BM, Blank D, Cianflone K. Plasma acylation stimulating protein, adipsin and lipids in non-obese and obese populations. Eur J Clin Invest 1999; 29: 679-686.

30 Cianflone K, Kalant D, Marliss EB, Gougeon R, Sniderman AD. Response of plasma ASP to a prolonged fast. Int J Obes Relat Metab Disord 1995; 19: 604-609.

31 Cianflone KM, Maslowska $\mathrm{MH}$, Sniderman AD. Impaired response of fibroblasts from patients with hyperapobetalipoproteinemia to acylation-stimulating protein. J Clin Invest 1990; 85: $722-730$.

32 Zhang XJ, Cianflone K, Genest J, Sniderman AD. Plasma acylation stimulating protein (ASP) as a predictor of impaired cellular biological response to ASP in patients with hyperapoB. Eur J Clin Invest 1998; 28: 730-739.

33 Schrauwen-Hinderling VB, van Loon LJ, Koopman R, Nicolay K, Saris WH, Kooi ME. Intramyocellular lipid content is increased after exercise in nonexercising human skeletal muscle. $J$ Appl Physiol 2003; 95: 2328-2332.

34 Cox JH, Cortright RN, Dohm GL, Houmard JA. Effect of aging on response to exercise training in humans: skeletal muscle GLUT-4 and insulin sensitivity. J Appl Physiol 1999; 86: 2019-2025.

35 Houmard JA, Shaw CD, Hickey MS, Tanner CJ. Effect of short-term exercise training on insulin-stimulated PI 3-kinase activity in human skeletal muscle. Am J Physiol 1999; 277: E1055-E1060.

36 Youngren JF, Keen S, Kulp JL, Tanner CJ, Houmard JA, Goldfine ID. Enhanced muscle insulin receptor autophosphorylation with short-term aerobic exercise training. Am J Physiol Endocrinol Metab 2001; 280: E528-E533.

37 Ahren B, Havel PJ, Pacini G, Cianflone K. Acylation stimulating protein stimulates insulin secretion. Int J Obes Relat Metab Disord 2003; 27: 1037-1043.

38 Romijn JA, Coyle EF, Sidossis LS, Gastaldelli A, Horowitz JF, Endert E, Wolfe RR. Regulation of endogenous fat and carbohydrate metabolism in relation to exercise intensity and duration. Am I Physiol Endocrinol Metab 1993; 265: E380-E391. 